\title{
"The relationship between zakat disclosures and Islamic banking performance: Evidence from Yemen"
}

\begin{tabular}{|c|c|}
\hline \multirow{7}{*}{ AUTHORS } & Eissa A. Al-Homaidi (D https://orcid.org/0000-0002-6230-8276 \\
\hline & R https://publons.com/researcher/3578411/eissa-a-al-homaidi/ \\
\hline & Ebrahim Mohammed Al-Matari (D https://orcid.org/0000-0001-9247-2766 \\
\hline & R https://publons.com/researcher/2374311/ebrahim-m-al-matari/ \\
\hline & Suhaib Anagreh id https://orcid.org/0000-0003-1751-7674 \\
\hline & Mosab I. Tabash iD https://orcid.org/0000-0003-3688-7224 \\
\hline & Nabil Ahmed Mareai Senan (D https://orcid.org/0000-0002-6848-588X \\
\hline ARTICLE INFO & $\begin{array}{l}\text { Eissa A. Al-Homaidi, Ebrahim Mohammed Al-Matari, Suhaib Anagreh, Mosab I. } \\
\text { Tabash and Nabil Ahmed Mareai Senan (2021). The relationship between zakat } \\
\text { disclosures and Islamic banking performance: Evidence from Yemen. Banks and } \\
\text { Bank Systems, 16(1), 52-61. doi:10.21511/bbs.16(1).2021.05 }\end{array}$ \\
\hline DOI & http://dx.doi.org/10.21511/bbs.16(1).2021.05 \\
\hline RELEASED ON & Tuesday, 23 February 2021 \\
\hline RECEIVED ON & Saturday, 05 December 2020 \\
\hline ACCEPTED ON & Monday, 15 February 2021 \\
\hline & $(\mathrm{cc}) \mathrm{EY}$ \\
\hline LICENSE & $\begin{array}{l}\text { This work is licensed under a Creative Commons Attribution } 4.0 \text { International } \\
\text { License }\end{array}$ \\
\hline JOURNAL & "Banks and Bank Systems" \\
\hline ISSN PRINT & $1816-7403$ \\
\hline ISSN ONLINE & $1991-7074$ \\
\hline PUBLISHER & LLC "Consulting Publishing Company "Business Perspectives" \\
\hline FOUNDER & LLC "Consulting Publishing Company "Business Perspectives" \\
\hline \multirow{2}{*}{ NUMBER OF REFERENCES } & 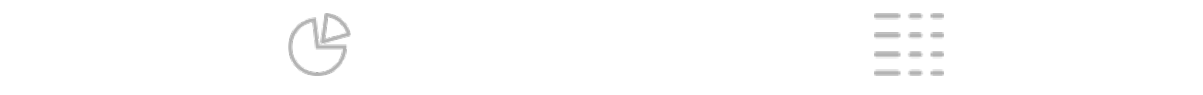 \\
\hline & NUMBER OF FIGURES \\
\hline 56 & 4 \\
\hline
\end{tabular}

(C) The author(s) 2021. This publication is an open access article. 


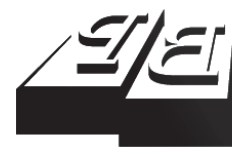

\section{BUSINESS PERSPECTIVES}

()

LLC "CPC "Business Perspectives"

Hryhorii Skovoroda lane, 10, Sumy, 40022, Ukraine

www.businessperspectives.org
Received on: $5^{\text {th }}$ of December, 2020 Accepted on: $15^{\text {th }}$ of February, 2021 Published on: $23^{\text {rd }}$ of February, 2021

(c) Eissa A. Al-Homaidi, Ebrahim Mohammed Al-Matari, Suhaib Anagreh, Mosab I. Tabash, Nabil Ahmed Mareai Senan, 2021

Eissa A. Al-Homaidi, Research Scholar Faculty of Commerce, Aligarh Muslim University, India. (Corresponding author)

Ebrahim Mohammed Al-Matari, Associate Professor of Accounting, College of Business, Jouf University, Kingdom of Saudi Arabia and Faculty of Commerce and Economics, Amran University, KSA.

Suhaib Anagreh, Assistant Professor, Abu Dhabi School of Management, Abu Dhabi, UAE.

Mosab I. Tabash, Assistant Professor, College of Business, Al Ain University, UAE.

Nabil Ahmed Mareai Senan, Associate Professor, Department of Accounting, College of Business Administration, Prince Sattam bin Abdul Aziz University, Kingdom of Saudi Arabia and Administrative Science College, Al-Baydha University, KSA.
Eissa A. Al-Homaidi (India), Ebrahim Mohammed Al-Matari (KSA),

Suhaib Anagreh (UAE), Mosab I. Tabash (UAE), Nabil Ahmed Mareai Senan (KSA)

THE RELATIONSHIP BETWEEN ZAKAT DISCLOSURES AND

\title{
ISLAMIC BANKING PERFORMANCE: EVIDENCE FROM YEMEN
}

\begin{abstract}
This paper aims to analyze the link between the disclosure of zakat information and the performance of Islamic financial institutions in Yemen. Panel data of three Islamic banks working in Yemen were used. The study used a 16-item disclosure index to measure zakat disclosure information, and the financial performance of banks was calculated using two proxies, such as return on assets (ROA) and return on equity (ROE). Based on secondary data, this study used correlation matrix, descriptive analysis and regression analysis. ROA results revealed that zakat data and the age of a bank significantly affected financial results calculated by ROA, while the size of Islamic banks had an insignificant influence of banking performance. Zakat information and the size of Islamic banks have a positive effect on bank performance, while the age of the bank negatively influences the performance of banks. The results concerning ROE indicated that zakat data and the age of a bank have a strong and significant influence on the performance of banks, determined by ROA, while the size of a bank has a negative and insignificant effect on the performance of banks, determined by ROE.
\end{abstract}

\section{Keywords}

JEL Classification

\section{INTRODUCTION}

Islamic financial institutions are considered one of the fastest-growing technologies and have received universal recognition as a result of this evolution (Abdou et al., 2014). Islamic economic organizations, therefore, "resort to Shari'ah academics forming Shari'ah supervisory boards (SSBs) in their attempts to ensure that their services stay in compliance with the Shari'ah guidelines". Nevertheless, "Islamic finance is not limited to stakeholders with common religious backgrounds. Britain has announced plans to turn London into the world Centre of Islamic finance" (Kerr, 2007), and BNP Paribas, international banks like Citigroup, Hong Kong and Shanghai Banking Corporation (HSBC) and others are also growing into this fresh sector segment. Also, UK, France, China, Singapore, and many other countries have developed special regulations to facilitate the working of Islamic banking (Nazim Ali, 2008).

This paper aims to test the link between zakat transparency and performance of Islamic banking in Yemen. This study used a harmonious transparency index of sixteen items to assess the disclosure about zakat data, while the quality of banks was assessed by return on assets (ROA) and return on equity (ROE). The study added to the published literature revealing zakat data in Yemen by Islamic institutions in Yemen. This is the first attempt to examine the link between both 
the transparency of zakat data and the quality of Islamic companies using the model of Islamic banks. The outcomes of this study have consequences for several classes of investors. The outcomes must be of importance to leadership, central banks, Accounting and Auditing Organization of Islamic Financial Institutions (AAOIFI), the Islamic Financial Services Board (IFSB) and the investigated country's accounting policymakers. These interested parties (for example, zakat evaders, zakat recipients, IAHs, creditors, clients, and the Immigrant population) should also benefit from such research findings in their production to generate valuable data.

This research seeks to fill the existing gap in the zakat transparency literature and contributes to the ongoing current work to determine the degree of zakat transparency in the financial reports of Islamic firms by examining the degree of zakat transparency in the financial reports of Yemeni Islamic firms, as well as to identify the impact of zakat transparency level on the financial performance of Yemeni Islamic financial institutions. There is a lack of research on financial reporting systems in Islamic banks. This is the latest study in Yemen examining the influence of the level of zakat disclosure on financial performance.

\section{LITERATURE REVIEW}

Many studies used ROA to measure financial performance (e.g., Al-Homaidi et al., 2019c; AlHomaidi et al., 2019b; Mendonça \& Bernardo, 2018; Ramlan \& Adnan, 2016), while other studies used ROE to measure performance (e.g., Javaid \& Alalawi, 2018; Peng et al., 2017). Zakat information was adopted by many prior studies (e.g., AlShammari, 2013; Srairi, 2015).

Nawaz and Haniffa (2017) reported that the effects of intangible assets are tested empirically, i.e., Intelligent Capital (IC), on the economic outcomes of 64 Islamic firms operating between 2007 and 2011 in 18 different countries, being adjusted for company-specific indicators, including bank volume, risk level, listing status, and business difficulty. The results state that there is an important beneficial connection between VAIC and transparency measured by ROA. The findings further reveal an important beneficial relationship between the quality of financial reporting and employed capital effectiveness and human capital effectiveness, but no important connection was found concerning structural capital effectiveness, and no important connection with regard to the effectiveness of structural capital. Trad et al. (2017) investigated the possibility of Islamic financial institutions being an option for standard banks and achieving stability in times of crisis. The study discovered that capital adequacy and the size of a bank are the primary variables accountable for decreasing credit risk, improving performance, and attaining the stability of Islamic financial institutions.
Sellami and Tahari (2017) studied the compliance of Islamic institutions in some Middle East and North African nations with reporting accounting standards and, most importantly, evaluated compliance factors. They use a self-built list of 203 items to determine compliance with transparency accounting standards by 38 Islamic banks in 2011-2013. Multivariate regression analysis showed a wide variation in compliance levels among the disclosure accounting standards and revealed that compliance was positively related to the listing status, the existence of an audit committee, the bank's age and the country of domicile.

Ahmad and Al-Homaidi (2018) specified that the size of an audit committee and board composition had the strongest revealed factors, while public ownership was the lowest disclosure factor for tourism firms. Maali et al. (2006) evaluate the financial reports of 29 Middle East Islamic institutions and note that their declarations on Corporate Social Responsibility (CSR) do not meet those standards. The research often compares CSR disclosures by zakat paid banking institutions with those of nonzakat paid financial institutions (such as zakat disclosures) and finds that zakat that must be paid by financial institutions provides more CSR disclosure of information than non-zakat paid banking institutions. Farook et al. (2011) find restricted social responsibility disclosure in Islamic financial institutions using the corporate social disclosure Index, created by Maali et al. (2006). Using seven Islamic finance bodies in the Arab Gulf region (with annual reports accessible from 2002 to 2004), Haniffa and Hudaib (2007) tested the difference 
among the "verbalized" (based on the data reported in the financial statements) and the "ideal" ("what must be disclosed in the annual Islamic values reports?") ones. Their findings support those of Maali et al. (2006) who report the degree of CSR transparency does not correspond to the perceptions of stakeholders of Islamic financial institutions as humane organizations with cultural-economic goals. Islamic financial institutions are anticipated to be more responsible in their behavior and procedures and should, therefore, be reported in financial statements on their responsibility (Haniffa \& Hudaib, 2007). Stockholders, owners of retirement accounts, zakat recipients and other actors (potential and current investors staff, clients, zakat recipients, federal and state authorities, and "Muslim society at large) are likely to demand the SSB to update zakat estimates and zakat allocations (Maali et al., 2006) and challenge zakat judgments (Bakar, 2007).

Noordin and Kassim (2019) examined the statistical correlation between the composition of the Sharia Committee and the degree of the transparency of Sharia governance in 16 Islamic institutions licensed in Malaysia. Before the performance accountability system is applied (SGF), the study showed a significant correlation between the different configurations of the Sharia Committee in Malaysian Islamic firms and their degree of Sharia Governance transparency.

Grassa et al. (2019) analyzed the impact of factors of corporate governance (CG) on the Corporate Social Responsibility Disclosure (CSRD) degree in 95 Islamic banking institutions in 2013. The results show that CG structures, the age of the company, auditor and audit department of shari'ah are successful in shaping SSBD, CSRD, and FD activities in Islamic institutions. Al-Sartawi and Reyad (2019) analyzed the relationship between online disclosure forms (OFD) and Islamic company profitability in the Gulf Cooperation Council (GCC) nations. They demonstrate that Islamic financial institutions' aggregate OFD in the GCC is 72.5 percent and there is a harmful and unimportant OFD-profit connection. Djaghballou et al. (2018) evaluated the efficiency and production output of zakat funds operated by the DRAE in Algeria. The results showed that the overall productivity variable for all zakat funds has increased significant- ly, primarily due to a change in technology rather than performance.

Arimurti and Wijayana (2019) determined the rate of zakat disclosure and the degree of political reporting of OPZs in Indonesia. The results show that zakat disclosure of OPZs in access to Indonesia belongs to good and medium groups with an average rating of $56.25 \%$. The highest reporting rate of OPZ is BAZNAS, with a ranking of $81.25 \%$. Therefore, the rate of consistency of OPZs in the reporting of financial statements based on PSAK 109 belongs to a very strong or very high class with an average of $84.98 \%$. OPZ with the highest possible level of BAZNAS complies with a disclosure rating of $95.74 \%$, followed by LAZ Rumah Zakat Indonesia with $95.14 \%$ and Yayasan Baitul Maal Muamalat with $89.38 \%$. Furthermore, the information volume and the public's availability of information have not become the OPZ's primary focus.

Sudirman et al. (2019) explicitly investigated Sharia Accounting, which deals with the evaluation of Zakat Centered on a comparative study between PSAK 109 and FAS (9) of the AAOIFI and made a draft Zakat Reporting Regulations based on a comparison of PSAK 109 with FAS (9) AAOIFI, which can be implemented in Indonesia. Al-Homaidi et al. (2020b) examined the link between the extent of disclosure practices and the profitability of Yemeni Islamic banks was investigated. It was found that the Islamic bank's history, details on corporate governance, corporate social disclosure, bank size, and bank age had a negative and important relationship with asset returns.

Accordingly, this study aims to explore the disclosure of zakat information of Yemen Islamic firms. Specifically, it empirically discusses the relationship between the transparency of zakat information and financial performance of Islamic institutions in the Republic of Yemen between 2005 and 2014.

This study seeks to fill the existing gap in the zakat transparency literature and adds to the ongoing study of the degree of zakat transparency in Islamic financial institutions by examining the degree of zakat transparency in Yemeni Islamic institutions' annual reports and by investigating the impact of zakat disclosure levels on the per- 
formance of Yemeni Islamic banks. There is a lack of research on financial reporting structures in Islamic firms, and this is the recent study in Yemen that explores the effect of zakat disclosure on financial performance. Therefore, this study extends and adds to previous studies, using panel information from three Yemeni Islamic companies from all over the world from 2005 to 2014 and comprehensively using various financial performance factors.

\section{METHODS}

\subsection{Dataset and study sample}

This study uses panel data of three Islamic banks $(60 \%)$ out of five Islamic financial firms working in Yemen from 2005 to 2014. The attempt has been made to include other Islamic financial institutions in the evaluation, but due to the non-availability of financial statements and data necessary for ten years of research, this is not possible. The study uses panel information for the period from 2005 to 2014 from three Yemeni Islamic institutions. A consistent transparency index of 16 items was used to calculate zakat data, while the quality of banks was evaluated using ROA and ROE. This paper is based on secondary data and uses a matrix of correlation descriptive analysis and analysis of regression. Two Islamic banks were excluded because of the non-availability of data - Alkuraimi
Islamic microfinance bank and Investment (2010) and Islamic Bank of Yemen for finance and investment (1995).

\subsection{Definition of research indicators}

\subsubsection{Dependent variables}

Financial performance (ROA and ROE). The performance of Islamic firms is the ratio defined by two proxies (ROA and ROE). Many of prior studies, such as Efobi and Bwala (2013), and Uyar et al. (2013), suggested that the reporting data was positively affected by performance. Hossain and Hammami (2009) confirmed that the performance ratio (ROE) has a marginal impact on the volunteer transparency rate. Hossain (2008) demonstrated that the effect of firm performance (ROA) on transparency information is important.

\subsubsection{Independent variables}

Zakat information (ZAKAT). The disclosure of zakat information of Yemeni Islamic banks is defined by 1 if the Islamic bank disclosed, or 0 otherwise. Many of prior studies used zakat information (Al-Shammari, 2013; Rahman \& Bukair, 2013; Srairi, 2015).

Age of a bank (BAGE). Bank age is estimated by the period of several years since setting up. In previous investigations, the bank age indicator is

Table 1. Definition of research indicators

\begin{tabular}{|c|c|c|c|c|c|}
\hline Indicators & Notation & Proxy & $\begin{array}{l}\text { Predicted } \\
\text { sign }\end{array}$ & $\begin{array}{l}\text { Source } \\
\text { of data }\end{array}$ & Previous research \\
\hline \multicolumn{6}{|c|}{ Dependent indicators (financial performance) } \\
\hline \multirow[t]{2}{*}{$\begin{array}{l}\text { Financial } \\
\text { performance }\end{array}$} & ROA & $R O A_{i t}=\frac{\text { Net Prof }}{\text { Total Assets }}$ & \pm & $\begin{array}{l}\text { Annual } \\
\text { reports }\end{array}$ & $\begin{array}{l}\text { Al-Homaidi et al. (2019c), Al-Homaidi et } \\
\text { al. (2019b), Javaid and Alalawi (2018), } \\
\text { Tabash et al. (2020), Al-Homaidi et al. } \\
\text { (2020a), Allamy et al. (2020), and Al- } \\
\text { Homaidi et al. (2021) }\end{array}$ \\
\hline & ROE & $R_{\text {OE }}=\frac{\text { Net Prof }_{i t}}{\text { Total Equity }}$ & \pm & $\begin{array}{l}\text { Annual } \\
\text { reports }\end{array}$ & $\begin{array}{l}\text { Javaid and Alalawi (2018), Lee and Hsieh } \\
\text { (2013), Olson and Zoubi (2017) }\end{array}$ \\
\hline \multicolumn{6}{|c|}{ Independent variables (zakat disclosure data) } \\
\hline $\begin{array}{l}\text { Zakat } \\
\text { information }\end{array}$ & ZAK & $\begin{array}{l}1 \text { if the Islamic institution } \\
\text { disclosed or } 0 \text { otherwise }\end{array}$ & NA & $\begin{array}{l}\text { Annual } \\
\text { reports }\end{array}$ & $\begin{array}{l}\text { Rahman and Bukair (2013) and Srairi } \\
\text { (2015) }\end{array}$ \\
\hline Age of bank & BAGE & Number of years from now & \pm & $\begin{array}{l}\text { Annual } \\
\text { reports }\end{array}$ & $\begin{array}{c}\text { Agarwal and Gort (2002), Mokni and } \\
\text { Rachdi (2014), Hawashe (2016), Chakroun } \\
\text { et al. (2017) }\end{array}$ \\
\hline Size of bank & BSIZE & Natural logarithm of total assets & \pm & $\begin{array}{l}\text { Annual } \\
\text { reports }\end{array}$ & $\begin{array}{l}\text { Pasiouras and Kosmidou (2007), Petria et } \\
\text { al. (2015), Shi and Wu (2017), Al-Homaidi } \\
\text { et al. (2019a) }\end{array}$ \\
\hline
\end{tabular}


generally adopted (Hossain \& Hammami, 2009). Some of the previous inquiries had a positive impact on mandatory reporting (Abeywardana \& Panditharathna, 2016), but other studies showed that compulsory reporting had a detrimental effect (Efobi \& Bwala, 2013).

Size of a bank (BSIZE). Size of Islamic firms is described by the total asset logarithm. Bank size surrogate is widely used by the previous investigations (e.g., Hossain \& Hammami, 2009; Mgammal, 2011, 2017; Nalikka, 2009; Naser et al., 2006; Premuroso, 2008). Several previous reviews showed a significant correlation between business size and voluntary dissemination of data (Aljifri et al., 2014). Haji and Ghazali (2013) and Uyar et al. (2013) pointed out that scale had a beneficial impact on voluntary information disclosures.

\subsection{Multiple regression models}

A regression test is developed to evaluate the relationship between zakat information and banking performance. The dependent indicators are performance determined by ROA and ROE; the independent factors are the transparency of zakat information in the financial reports of Yemeni Islamic businesses. Multiple regressions are presented below:

$$
\begin{aligned}
& \text { Financial Performance }=\alpha_{i}+\beta_{1} Z A K_{i t}+ \\
& +\beta_{2} B_{i t} E_{i t}+\beta_{3} B A G E_{i t}+\varepsilon, \\
& R O A=\alpha_{i}+\beta_{1} Z A K_{i t}+\beta_{2} B S I Z E_{i t}+ \\
& +\beta_{3} B A G E_{i t}+\varepsilon,
\end{aligned}
$$

Table 2. Descriptive statistics

$$
\begin{aligned}
& R O E=\alpha_{i}+\beta_{1} Z A K_{i t}+\beta_{2} B S I Z E_{i t}+ \\
& +\beta_{3} B A G E_{i t}+\varepsilon
\end{aligned}
$$

where $R O A$ and $R O E$ are Islamic banks' performance proxies; $Z A K_{i t}=$ zakat information; $B S I Z E_{i t}=$ logarithm of total assets; $B A G E_{i t}=$ number of years since the foundation; $\alpha_{i}$ is a constant term; $i=1, N$ and $t=1, \ldots, T$.

Disclosure index score of zakat information was developed to investigate the degree of voluntary transparency: 1 if the bank disclosed or 0 otherwise (Cooke, 1989).

\section{RESULTS}

\subsection{Descriptive statistics}

Table 2 indicates the descriptive outcomes of the relationship between zakat disclosures and the performance of Islamic firms in Yemen. The descriptive statistics show the values of a mean, median, max, min, and standard deviation. The max values of $R O A$ and $R O E$ are 0.024 , and 0.258 , whereas the min values are 0.004 and 0.140 , respectively. Further, the average and median values of ROA, ROE, ZAK, BSIZE, and BAGE are 0.013, $0.178,0.313,18.952$, and 11.5 , respectively, while median values are $0.012,0.168,0.270,18.910$, and 11.5 , respectively. Maximum values of zakat information (ZAK), bank size (BSIZE), and bank age

\begin{tabular}{|c|c|c|c|c|c|c|}
\hline Indicators & Observations & Mean & Median & Maximum & Minimum & Std. dev. \\
\hline ROA & 30 & 0.013 & 0.012 & 0.024 & 0.004 & 0.005 \\
\hline ROE & 30 & 0.178 & 0.168 & 0.258 & 0.140 & 0.031 \\
\hline ZAK & 30 & 0.313 & 0.270 & 0.400 & 0.270 & 0.057 \\
\hline BSIZE & 30 & 18.952 & 18.910 & 23.670 & 16.660 & 1.576 \\
\hline BAGE & 30 & 11.5 & 11.5 & 19 & 3 & 4.183 \\
\hline
\end{tabular}
$(B A G E)$ are $0.258,0.400,23.670,19$, while minimum values are $0.140,0.270$, and $16.660,3$ respectively. The standard deviation values of $R O A, R O E$, ZAK, BSIZE, and BAGE are 0.005, 0.031, 0.057, 1.576 , and 4.183 , respectively.

Notes: $R O A$ is the net profit ratio after-tax/total assets, ROE is the net profit ratio after-tax/total investors, ZAK is the zakat information, $B S I Z E$ is measured by the logarithm of total assets, and $B A G E$ is the ratio measured by the number of years since the establishment. 


\subsection{Correlation analysis}

Table 3 reveals the correlation matrix results of this examination. The results indicated that zakat information (ZAK), bank size (BSIZE), and bank age $(B A G E)$ have a positive correlation with banks' performance calculated by ROA. Zakat data $(Z A K)$ and bank size (BSIZE) have a positive correlation with the performance of Islamic banks determined by $R O E$, while Islamic banks' age (BAGE) has a negative relationship with banks' performance calculated by ROE. Zakat information (ZAK) has the highest average with bank age, while bank age has the weakest mean with $R O A$. The results of this study show that there are no Malticoleanrity diagnoses among the indicators, since all values are less than 0.80 .

\subsection{Regression analysis}

Table 4 provides the regression technique results from 2005 to 2014. The purpose of this examination is to test the effect of zakat information disclosure on the quality of Islamic institutions in Yemen. The adjusted R-squared values for $R O A$ and $R O E$ are $38 \%$ and $19 \%$, which means that all variables (ZAK, BSIZE, and BAGE) gave about $38 \%$ of $R O A$ and $19 \%$ of $R O E$.

Table 3. Correlation matrix
The results concerning ROA revealed that zakat information $(Z A K)$ and bank age (BAGE) have a great impact on the productivity of financial institutions calculated by $R O A$, while bank size of Islamic firms (BSIZE) has a insignificant effect of banks' profitability. Zakat information $(Z A K)$ and bank size of Islamic firms (BSIZE) have a positive influence on the output of banks, while bank age (BAGE) has a detrimental influence on the profitability of financial institutions. The results with regard to ROE indicated that zakat data $(Z A K)$ and bank age (BAGE) have a strong and positive effect on banks' profitability calculated by $R O A$, whereas bank size of Islamic banks (BSIZE) has an adverse and negative influence on the profitability of financial institutions defined by $R O E$.

\section{DISCUSSION}

This section shows the findings and discussion of this study. It has been found that there is a strong relationship between zakat disclosure information and financial performance in Islamic banks working in Yemen during the study period from 2005 to 2016, while the size of Islamic banks has an insignificant effect on banking performance. Zakat

\begin{tabular}{|c|c|c|c|c|c|}
\hline Variables & ROA & ROE & Zakat information & Bank size & Bank age \\
\hline$R O A$ & 1.000 & - & - & - & - \\
\hline$R O E$ & 0.584 & 1.000 & - & - & - \\
\hline ZAK & 0.186 & 0.297 & 1.000 & - & - \\
\hline$B S I Z E$ & 0.277 & 0.336 & 0.292 & 1.000 & - \\
\hline$B A G E$ & -0.388 & -0.129 & 0.608 & 0.057 & 1.000 \\
\hline
\end{tabular}

Table 4. Regression analysis

\begin{tabular}{|c|c|c|c|c|c|c|c|c|}
\hline \multirow{2}{*}{ Variables } & \multicolumn{4}{|c|}{ ROA } & \multicolumn{4}{|c|}{ ROE } \\
\hline & Coeff. & Std. error & T-statistic & Prob. & Coeff. & Std. error & T-statistic & Prob. \\
\hline C & -0.001 & 0.008 & -0.095 & 0.925 & 0.053 & 0.062 & 0.845 & 0.406 \\
\hline ZAK & 0.049 & 0.015 & 3.154 & $0.004^{* * *}$ & 0.272 & 0.118 & 2.301 & $0.030 * *$ \\
\hline$B S I Z E$ & 0.000 & 0.000 & 0.920 & 0.366 & 0.004 & 0.003 & 1.210 & 0.237 \\
\hline CAGE & -0.001 & 0.000 & -4.137 & $0.000 * * *$ & -0.003 & 0.002 & -2.127 & $0.043^{* *}$ \\
\hline$R$-squared & - & - & - & 0.450 & - & - & - & 0.281 \\
\hline Adjusted $R$-squared & - & - & - & 0.387 & - & - & - & 0.199 \\
\hline Observations & - & - & - & 30 & - & - & - & 30 \\
\hline Durbin-Watson statistic & - & - & - & 1.517 & - & - & - & 1.248 \\
\hline F-statistic & - & - & - & 7.101 & - & - & - & 3.395 \\
\hline Prob. (F-statistic) & - & - & - & 0.001 & - & - & - & 0.033 \\
\hline
\end{tabular}

Notes: * significant at the level of $1 \%, * *$ significant at the level of $5 \%$, and $* * *$ significant at the level of $10 \%$. 
information items and bank size have a positive effect on banks' performance, except bank age having a negative influence on banks' performance. With respect to return on equity, the results indicate that zakat data and bank age have a strong and important influence on the banks' performance, whereas the size of a bank has a negative and insignificant effect on banks' performance determined by ROE.

The results presented in this study may be useful to managers, policymakers, international and regional bodies, investors, financial providers, academic researchers, society, and government work- ing to improve the performance of their banks. They should raise management awareness of the importance of voluntary disclosures to improve/ limit bank efficiency. The results of this analysis include information on voluntary transparency of zakat that has a significant influence on the financial results of Islamic firms operating in Yemen. These voluntary disclosures of zakat should be considered by management, policymakers, foreign and regional bodies, stakeholders, financial providers, and university researchers if study is aimed at improving the quality of institutions. The results of this paper may also be of interest to holders, depositors, and creditors.

\section{CONCLUSION}

This paper aims to analyze the correlation between the disclosure of zakat information and Islamic banks' performance in Yemen. Panel data of three Islamic banks of Yemen was used. This study used a disclosure index of 16 items to measure zakat information, whereas banks' profitability was calculated by ROA and ROE. The study was based on secondary data and used correlation matrix, descriptive analysis, and regression analysis.

The results with respect to ROA reveal that zakat data and bank age have a constructive impact on financial performance calculated by ROA, while the size of Islamic banks has a insignificant influence of firms' performance. Zakat data and size of Islamic banks have a positive effect on banks' performance, except bank age having a detrimental effect on the performance of Islamic institutions. The outcomes concerning ROE indicated that zakat data and age of companies have a positive and constructive impact on banks' performance measured by ROE, while the size of Islamic institutions has a negative and insignificant effect on banks' performance calculated by ROE. This paper has added to the literature of education that Islamic banks in Yemen provide disclosure of zakat information in Yemen.

This article bridges the gap in zakat disclosure and literature on financial quality and performance in the republic of Yemen. Therefore, this analysis expands on the use of panel data and contributes to prior studies of three Yemeni Islamic institutions from different regions from 2005 to 2014 and uses different financial performance indicators. The analysis suggested increasing the transparency of financial statements on zakat data and accountability and making it available to all stakeholders to protect their money to shareholders and investors. Future research may increase the sample or study period. In the future, comparative research could be carried out, for example, between Islamic institutions in Yemen and traditional companies in the republic of Yemen, or between Yemen and another country. Future research can explore this issue, for example, additional parameters or other analysis techniques such as GMM, ARDL or many other methods.

\section{AUTHOR CONTRIBUTIONS}

Conceptualization: Eissa A. Al-Homaidi, Ebrahim Mohammed Al-Matari, Suhaib Anagreh, Nabil Ahmed Mareai Senan.

Data curation: Eissa A. Al-Homaidi, Suhaib Anagreh, Mosab I. Tabash.

Formal analysis: Ebrahim Mohammed Al-Matari, Mosab I. Tabash, Nabil Ahmed Mareai Senan. Investigation: Eissa A. Al-Homaidi, Ebrahim Mohammed Al-Matari, Suhaib Anagreh, Nabil Ahmed Mareai Senan. 
Methodology: Eissa A. Al-Homaidi, Ebrahim Mohammed Al-Matari, Mosab I. Tabash, Nabil Ahmed Mareai Senan.

Project administration: Suhaib Anagreh.

Resources: Suhaib Anagreh, Mosab I. Tabash.

Software: Suhaib Anagreh, Mosab I. Tabash.

Supervision: Eissa A. Al-Homaidi, Ebrahim Mohammed Al-Matari, Suhaib Anagreh.

Validation: Eissa A. Al-Homaidi, Ebrahim Mohammed Al-Matari, Mosab I. Tabash, Nabil Ahmed

Mareai Senan.

Visualization: Eissa A. Al-Homaidi, Suhaib Anagreh, Nabil Ahmed Mareai Senan.

Writing - original draft: Eissa A. Al-Homaidi, Mosab I. Tabash.

Writing - reviewing \& editing: Ebrahim Mohammed Al-Matari, Suhaib Anagreh, Nabil Ahmed Mareai Senan

\section{REFERENCES}

1. Abdou, H. A., Muslem, O. A., \& Ismal, R. (2014). Risk management practices in the republic of Yemen: Are Islamic banks different? Journal of Islamic Economics, Banking and Finance, 10(3), 46-73. Retrieved from http://eprints.hud. ac.uk/id/eprint/20278/

2. Abeywardana, N. L. E., \& Panditharathna, K. M. (2016). The extent and determinants of voluntary disclosures in annual reports: Evidence from banking and finance companies in Sri Lanka. Accounting and Finance Research, 5(4), 147-162. https://doi org/10.5430/afr.v5n4p147

3. Agarwal, R., \& Gort, M. (2002). Firm and product life cycles and firm survival. American Economic Review, 92(2), 184-190. https://doi org/10.1257/000282802320189221

4. Ahmad, A., \& Al-Homaidi, E. A. (2018). Disclosure of corporate governance practices in Indian Tourism companies. International Journal of Research, 5(15), 660-678. Retrieved from https://journals. pen2print.org/index.php/ijr/article/view/14596

5. Al-Homaidi, E. A., Ahmad, A., Khaled, A. S. D., \& Qaid, M. M. (2019a). External factors and banks' performance: An empirical examination of commercial banks listed on Bombay Stock Exchange BSE. International Journal of Emerging Technologies and Innovative Research, 6(6), 368-371. Retrieved from http://www.jetir. org/papers/JETIR1907T24.pdf
6. Al-Homaidi, E. A., Almaqtari, F. A., Ahmad, A., \& Tabash, M. I. (2019b). Impact of corporate governance mechanisms on financial performance of hotel companies: Empirical evidence from India. African Journal of Hospitality, Tourism and Leisure, 8(2), 1-21. Retrieved from https://www.researchgate. net/publication/332036919_Impact_of_Corporate_Governance_ Mechanisms_on_Financial_Performance_of_Hotel_Companies_Empirical_Evidence_from_India

7. Al-Homaidi, E. A., Al-Matari, E. M., Tabash, M. I., Khaled, A. S. D., \& Senan, N. A. M. (2021). The influence of corporate governance characteristics on profitability of Indian firms: An empirical investigation of firms listed on Bombay Stock Exchange. Investment Management and Financial Innovations, 18(1), 114-125. https:// doi.org/10.21511/imfi.18(1).2021.10

8. Al-Homaidi, E. A., Farhan, N. H. S., Alahdal, W. M., Khaled, A. S. D., \& Qaid, M. M. (2020a). Factors affecting profitability of Indian listed firms: a panel data approach. International Journal of Business Excellence, 23(1), 1-17. https://doi. org/10.1504/IJBEX.2021.111928

9. Al-Homaidi, E. A., Tabash, M. I., \& Ahmad, A. (2020b). The profitability of Islamic banks and voluntary disclosure: empirical insights from Yemen. Cogent Economics and Finance, 8(1), 1-22. https://doi.org/1 $0.1080 / 23322039.2020 .1778406$
10. Al-Homaidi, E. A., Tabash, M. I., Farhan, N. H., \& Almaqtari, F. A. (2018). Bank-specific and macro-economic determinants of profitability of Indian commercial banks: A panel data approach. Cogent Economics \& Finance, 6(1), 1-26. https://doi.org/10.1080/2332 2039.2018.1548072

11. Al-Homaidi, E. A., Tabash, M. I., Farhan, N. H., \& Almaqtari, F. A. (2019c). The determinants of liquidity of Indian listed commercial banks: A panel data approach. Cogent Economics \& Finance, 7(1), 1-20. https://doi.org /10.1080/23322039.2019.1616521

12. Aljifri, K., Alzarouni, A., Ng, C., \& Tahir, M. I. (2014). The association between firm characteristics and corporate financial disclosures: evidence from UAE companies. The International Journal of Business and Finance Research, 8(2), 101124. Retrieved from https://ssrn. com/abstract $=2322965$

13. Allamy, K. K., Moh, A., Ahmad, A., \& Al-Homaidi, E. A. (2020). Influence of internal and macro factors on profitability of Indian commercial banks: empirical study. Studies in Economics and Business Relations, 1(1), 20-26. https://doi.org/10.48185/sebr. v1i1.74

14. Almaqtari, F. A., Al-Homaidi, E. A., Tabash, M. I., \& Farhan, N. H. (2018). The determinants of profitability of Indian commercial banks: A panel data approach. 
International Journal of Finance \& Economics, 24(1), 168-185. https:// doi.org/10.1002/ijfe.1655

15. Al-Sartawi, A. M. A. M., \& Reyad, S. M. R. (2019). The relationship between the extent of online financial disclosure and profitability of Islamic banks. Journal of Financial Reporting and Accounting, 17(2), 343-362. https:// doi.org/10.1108/JFRA-11-20170103

16. Al-Shammari, B. (2013). An investigation of voluntary disclosure by Kuwaiti Shariahcompliant companies. Journal of Economic and Administrative Sciences, 29(1), 21-41. https://doi. org/10.1108/10264111311319213

17. Arimurti, R., \& Wijayana, S. E. (2019). Analisis tingkat pengungkapan zakat dan laporan keuangan pada organisasi pengelola zakat di Indonesia (Doctoral Thesis). Universitas Gadjah Mada. Retrieved from https://journal.ugm. ac.id/abis/article/view/58853

18. Bakar, N. B. (2007). A zakat accounting standard ZAS for Malaysian companies. American Journal of Islamic Social Sciences, 24(4), 74-92. https://doi. org/10.35632/ajiss.v24i4.430

19. Chakroun, R., Matoussi, H., \& Mbirki, S. (2017). Determinants of CSR disclosure of Tunisian listed banks: A multi support analysis. Social Responsibility Journal, 13(3), 552-584. https://doi.org/10.1108/ SRJ-04-2016-0055

20. Cooke, T. E. (1989). Disclosure in the corporate annual reports of Swedish companies. Accounting and Business Research, 19(74), 113 124. https://doi.org/10.1080/00014 788.1989.9728841

21. Djaghballou, C., Djaghballou, M., Larbani, M., \& Mohamad, A. (2018). Efficiency and productivity performance of zakat funds in Algeria. International Journal of Islamic and Middle Eastern Finance and Management, 11(3), 474-494. https://doi.org/10.1108/ IMEFM-07-2017-0185

22. Efobi, U. R., \& Bwala, A. (2013). Voluntary information disclosure practices of listed companies in Nigeria. ICAV Journal of Accounting \& Finance, 2(1), 1330. http://dx.doi.org/10.2139/ ssrn.2378577

23. Farook, S., Hassan, M. K., \& Lanis, R. (2011). Determinants of corporate social responsibility disclosure: the case of Islamic banks. Journal of Islamic Accounting \& Business Research, 2(2), 114-141. https://doi. org/10.1108/17590811111170539

24. Grassa, R., El-Halaby, S., \& Hussainey, K. (2019). Corporate governance and multi-corporate disclosures evidence from Islamic banks. In T. Azid, A. A. Alnodel, \& M. A. Qureshi (Eds.), Research in Corporate and Shariah Governance in the Muslim World: Theory and Practice (pp. 167-187). Emerald Publishing Limited. https://doi.org/10.1108/978-178973-007-420191014

25. Haji, A. A., \& Ghazali, N. A. M. (2013). The quality and determinants of voluntary disclosures in annual reports of Shari'ah compliant companies in Malaysia. Humanomics, 29(1), 24-42. https://doi. org/10.1108/08288661311299303

26. Haniffa, R. M., \& Hudaib, M. (2007), Exploring the ethical identity of Islamic banks via communication in annual reports. Journal of Business Ethics, 76, 97-116. https://doi.org/10.1007/ s10551-006-9272-5

27. Hawashe, A. A. (2016). Commercial banks' attributes and annual voluntary disclosure: The case of Libya. International Journal of Accounting and Financial Reporting, 5(2), 208-233. https:// doi.org/10.5296/ijafr.v5i2.8684

28. Hossain, M. (2008). The extent of disclosure in annual reports of banking companies: The case of India. European Journal of Scientific Research, 23(4), 660-681. http://hdl.handle.net/10576/10429

29. Hossain, M., \& Hammami, H. (2009). Voluntary disclosure in the annual reports of an emerging country: The case of Qatar. Advances in Accounting, 25(2), 255-265. https://doi.org/10.1016/j. adiac.2009.08.002
30. Javaid, S., \& Alalawi, S. (2018). Performance and profitability of Islamic banks In Saudi Arabia: An empirical analysis. Asian Economic and Financial Review, 8(1), 38-51. https://doi.org/10.18488/journal. aefr.2018.81.38.51

31. Kerr, S. (2007). DIFC Investments Issues Islamic Bond. Financial Times. Retrieved from https:// www.ft.com/content/494200181528-11dc-b48a-000b5df10621

32. Lee, C., \& Hsieh, M. (2013). The impact of bank capital on profitability and risk in Asian banking. Journal of International Money and Finance, 32, 251-281. https://doi.org/10.1016/j.jimonfin.2012.04.013

33. Maali, B., Casson, P., \& Napier, C. (2006). Social reporting by Islamic banks. ABACUS, 42(2), 266-289. https://doi.org/10.1111/j.14676281.2006.00200.x

34. Mendonça, H. F., \& Bernardo, R. (2018). Effect of banking and macroeconomic variables on systemic risk: An application of $\triangle$ COVAR for an emerging economy. North American Journal of Economics and Finance, 43, 141-157. https://doi.org/10.1016/j. najef.2017.10.011

35. Mgammal, M. H. (2011). Voluntary disclosure and ownership structure among Saudi Arabia companies (Doctoral Thesis). Universiti Utara Malaysia. Retrieved from http://etd.uum. edu.my/id/eprint/2787

36. Mgammal, M. H. (2017). The effect of ownership structure on voluntary disclosure: Evidence from Saudi Arabia. Journal of Advanced Management Science, 5(2), 138-151. https://doi. org/10.18178/joams.5.2.138-151

37. Mokni, R. B. S., \& Rachdi, H. (2014). Assessing the bank profitability in the MENA region A comparative analysis between conventional. International Journal of Islamic and Middle Eastern Finance and Management, 7(3), 305-332. https://doi.org/10.1108/IMEFM-03-2013-0031 
38. Nalikka, A. (2009). Impact of gender diversity on voluntary disclosure in annual reports. Accounting \& Taxation, 1(1), 101113. Retrieved from https://ssrn. com/abstract $=1555069$

39. Naser, K., Al-Hussaini, A., AlKwari, D., \& Nuseibeh, R. (2006). Determinants of corporate social disclosure in developing countries: The case of Qatar. Advances in International Accounting, 19, 1-23. https://doi.org/10.1016/S08973660(06)19001-7

40. Nawaz, T., \& Haniffa, R. (2017) Determinants of financial performance of Islamic banks: an intellectual capital perspective. Journal of Islamic Accounting and Business Research, 8(2), 130142. https://doi.org/10.1108/ JIABR-06-2016-0071

41. Nazim Ali, S. (2008). Islamic finance and economics as reflected in research and publications. Review of Islamic Economics, 12(1), 151-168. Retrieved from https:// citeseerx.ist.psu.edu/viewdoc/dow nload?doi $=10.1 \cdot 1 \cdot 628.3405 \& \mathrm{rep}=\mathrm{r}$ ep1\&type $=$ pdf

42. Noordin, N., \& Kassim, S. (2019). Does Shariah committee composition influence Shariah governance disclosure? Evidence from Malaysian Islamic banks. Journal of Islamic Accounting and Business Research, 10(2), 158184. https://doi.org/10.1108/ JIABR-04-2016-0047

43. Olson, D., \& Zoubi, T. (2017). Convergence in bank performance for commercial and Islamic banks during and after the Global Financial Crisis. Quarterly Review of Economics and Finance, 65, 71-87. https://doi.org/10.1016/j. qref.2016.06.013

44. Pasiouras, F., \& Kosmidou, K. (2007). Factors influencing the profitability of domestic and foreign commercial banks in the European Union. Research in International Business and Finance, 21(2), 222-237. https://doi org/10.1016/j.ribaf.2006.03.007

45. Peng, J., Jeng, V., Wang, J. L., \& Chen, Y. (2017). The impact of bancassurance on efficiency and profitability of banks:
Evidence from the banking industry in Taiwan. Journal of Banking and Finance, 80, 1-13. https://doi.org/10.1016/j.jbankfin.2017.03.013

46. Petria, N., Capraru, B., \& Ihnatov, I. (2015). Determinants of banks' profitability: evidence from EU 27 banking systems. Procedia Economics and Finance, 20, 518524. https://doi.org/10.1016/ S2212-56711500104-5

47. Premuroso, R. F. (2008). An analysis of voluntary annual report disclosures of outsourcing: Determinants and firm performance (Doctoral Thesis). Florida Atlantic University. Retrieved from https://search. proquest.com/openview/84a3844 2747674 eb0d2b653501a725da/1? pq-origsite $=$ gscholar $\& \mathrm{cbl}=18750$ \&diss $=\mathrm{y}$

48. Rahman, A. A., \& Bukair, A. A. (2013). The influence of the Shariah Supervision Board on corporate social responsibility disclosure by Islamic banks of Gulf Co-operation Council Countries. Asian Journal of Business and Accounting, 6(2), 65104. Retrieved from https://ajba. um.edu.my/article/view/2678

49. Ramlan, H., \& Adnan, M. S. (2016). The profitability of Islamic and conventional bank: Case study in Malaysia. Procedia Economics and Finance, 35, 359-367. Retrieved from https://daneshyari. com/article/preview/979858.pdf

50. Sellami, Y. M., \& Tahari, M. (2017). Factors influencing compliance level with AAOIFI financial accounting standards by Islamic banks. Journal of Applied Accounting Research, 18(1), 137-159. https://doi.org/10.1108/ JAAR-01-2015-0005

51. Shi, X., \& Wu, Y. (2017). The effect of internal and external factors on innovative behaviour of Chinese manufacturing firms. China Economic Review, 46, 50-64. https://doi.org/10.1016/j.chieco.2016.08.010

52. Srairi, S. (2015). Corporate governance disclosure practices and performance of Islamic banks in GCC countries. Journal of
Islamic Finance, 4(2), 1-17. https:// doi.org/10.12816/0024085

53. Sudirman, M., Zaenal, M. H., \& Pramono, S. E. (2019). Zakat, accounting of zakat, sak design of zakat accounting guidelines based on comparative analysis of PSAK 109 and FAS (9) AAOIFI. In International Conference of Zakat (pp.216-231). https://doi. org/10.37706/iconz.2019.179

54. Tabash, M., Al-Homaidi, E. Ahmad, A., \& Hamood, N. (2020). Factors affecting financial performance of Indian firms: An empirical investigation of firms listed on Mumbai Stock Exchange (MSE). International Journal of Economic Policy in Emerging Economies, 13(2), 1. Retrieved from https://www.researchgate. net/publication/341613756_Factors_Affecting_Financial_Performance_of_Indian_Firms_An_Empirical_Investigation_of_Firms_ Listed_on_Mumbai_Stock_Exchange_MSE

55. Trad, N., Trabelsi, M. A., \& Goux, J. F. (2017). Risk and profitability of Islamic banks: A religious deception or an alternative solution? European Research on Management and Business Economics, 23(1), 40-45. https://doi.org/10.1016/j.iedeen.2016.09.001

56. Uyar, A., Kilic, M., \& Bayyurt, N. (2013). Association between firm characteristics and corporate voluntary disclosure: Evidence from Turkish listed companies. Intangible Capital, 9(4), 1080-1112. Retrieved from http://hdl.handle. net/2117/80866 